\title{
Studies on Genetic Variability, Heritability, Genetic Advances and Association of Morpho-Physiological Traits and their Relation with Heat Tolerance in Wheat
}

\author{
Nishant Bankapur, J.S. Hilli ${ }^{*}$, Ram Dhari and B. Arun \\ Department of Seed Science and Technology, College of Agriculture, \\ University of Agricultural Sciences, Dharwad-580005, Karnataka (India) \\ *Corresponding author:
}

\section{A B S T R A C T}

\section{Keywords}

Genetic variability, Genetic advance, Heritability, Heat tolerance, Morphophysiological traits, Wheat

Article Info

Accepted:

20 November 2018

Available Online:

10 December 2018
What is an important food crop in India but of the entire world. The study indicates that the analysis of the variance showed highly significant differences for all the characters. Genetic variability indicated that high estimates of GCV and PCV were observed for the traits like 1000 grain weight, grains per spike, spikelets per spike, spike length and yield per plot. Further, high heritability coupled with high genetic advance as percent of mean was also observed, indicating the less influence of environmental variance in these characters. Correlation study revealed that plot yield had strong positive association with 1000 grain weight, spike length, spikelet's per spike. The results seed yield and on CTD and chlorophyll content have strong association indicating that these characters are helpful for selection for heat tolerance wheat genotypes.

\section{Introduction}

Wheat (Triticum aestivum L.), belonging to the family Poaceae, is an important staple food crop not only India but the entire world. It occupies a unique position in the human life as it is the main source of food and energy with a large number of end use products like chapathi, bread, biscuits, pasta and is also a good source of fodder for the animals. Wheat is grown on 217 million hectares throughout the world with a production of 640 million tonnes of grain annually (FAO, 2008). It provides, on an average, one fifth of total calorific input to the world population (FAO, 2003) of the cultivated wheat area, half of it is located in less developed countries where these have been steady increased productivity since green revolution, associated with genetic improvement in yield potential (Reynolds and Borlaug, 2006).

Since, the green revolution in the mid sixties, India achieved a remarkable increase in production and productivity of wheat. This is an indicative from the fact that the total 
production in India has increased to the magnitude of more than six folds from roughly 12.3 million tonnes in 1964-65 to 81 million tonnes in 2008-09. India has firmed up its position as one of the principle wheat producing countries in the world, the second largest producer next to China. With the increase in the population, the demand for wheat is also increasing such that, by 2020 it is expected that country's demand for wheat will be 88 million tonnes. Wheat production in recent years has reached a plateau where further increase in the productivity and yield is rather difficult. Realising the $88 \mathrm{mt}$. $\operatorname{targ} e t$ al.,ong with the constraints of biotic and abiotic stresses is a greater challenge to the wheat crop scientists and plant breeders.

The prerequisite of any breeding program is the evaluation of existing genetic stock. The success of any systematic breeding programme depends mainly on the judicious selection and use of promising parents from the stock. Therefore, the knowledge regarding the existence of genetic variability in the genetic stock and association between different morphological and physiological characters and their effect on final yield is helpful.

The efficiency of selection largely depends upon the magnitude of significant variability present in the plant population. Heritability and genetic advance are important selection parameters. Heritability is a good index of the transmission of characters from parents to their offspring (Falconer, 1981). Genetic advance is the measure of genetic gain under selection. Thus, genetic advance denotes the improvement in the mean genotypic value of selected population over the parental population. Heritability estimates along with genetic advance are more hopeful in predicting the improvement that can be made in a crop by selecting the elite genotypes for various characters.
The nature and relationship between yield and its component traits and also among other traits seem to provide information, which would be of greater value at the time of practising selection for improved yield. For fixation of the characters that are contributing towards yield, the knowledge regarding relative contribution of individual trait to yield is very important and this can be accomplished by partitioning the correlation coefficient into direct and indirect effects (Allard, 1960). The quantitative traits are under polygenic control and are considerably influenced by an environment to which the individual is exposed. Simple correlation studies do provide adequate information about the contribution of each factor towards the yield (Wright, 1921).

In view of the above facts, the present investigation on "studies on genetic variability and association among different morphophysiological traits and their relation with heat tolerance in wheat" was undertaken with the following objectives.

To estimate the Genetic variability, heritability and genetic advance for some morphophysiological traits in wheat.

To study the association among different morpho-physiological traits.

\section{Materials and Methods}

An experiment was laid out in randomised block design with three replications, consisting of 50 wheat varieties sown on $3^{\text {rd }}$ December 2010 with spacing of $23 \mathrm{~cm}$ between the rows. The biometric observations were recorded on days to $50 \%$ flowering, canopy temperature depression (CTD) between 12 hours to 15 hours at 7 days interval from tillering (vegetative) stage up to dough stage, a total of 6 CTD measurements were taken. CTD was calculated using the 
formula of: $\mathrm{CTD}=$ Air temperature $(\mathrm{Ta})-$ canopy temperature (Tc), chlorophyll content was measured with rapid estimation of the chlorophyll level in leaves using the Minolta SPD-502 meter; Days to anthesis, days to maturity, plant height $(\mathrm{cm})$, spike length $(\mathrm{cm})$, No. of spikelet's per spike, grains per spike, 1000 seed weight $(\mathrm{g})$ and plot yield $(\mathrm{g})$. The mean data of these parameters obtained in the field were subjected to statistical analysis of variance and co-variance. Heritability genetic advance and correlation co-efficient (Panse and Sukhatame, 1967). Phenotypic, genotypic and environmental co-efficient of variability was calculated as per the method proposed by Burton (1952). Analysis of variance (ANOVA) is given below.

Skeleton of Analysis of variance (ANOVA)

\begin{tabular}{|c|c|c|c|c|}
\hline Source & $d f$ & SS & MSS & $\begin{array}{l}\text { F value } \\
\text { (Calculated) }\end{array}$ \\
\hline Replication & $r-1$ & SSr & $\frac{S S r}{(r-1)}=M S R$ & \multirow{4}{*}{$\begin{array}{l}\text { MST } \\
\text { MSE }\end{array}$} \\
\hline Treatment & $t-1$ & SSt & $\begin{array}{l}\text { SSt } \\
\frac{(t-1)}{}=M S T\end{array}$ & \\
\hline Error & $(r-1)(t-1)$ & SSe & $\frac{S S e}{(r-1)(t-1)}=M S E$ & \\
\hline Total & (rt-1) & TSS & & \\
\hline
\end{tabular}

Where,

$\mathrm{r}=$ number of replications

$\mathrm{t}=$ number of treatments

df $=$ degree of freedom

$\mathrm{SSr}=$ replication sum of squares

$\mathrm{SSt}=$ treatment sum of squares

$\mathrm{SSe}=$ error sum of squares

TSS $=$ Total sum of squares

MST = treatment mean sum of squares

MSR $=$ replication mean sum of squares

$\mathrm{MSE}=$ error mean sum of squares

The genetic variability mean, range, components of variance, such as genotypic, phenotypic, environmental, SMI, CD, CV were calculated. PCV (\%), GCV (\%), ECV (\%) were also calculated using formula given by Burton (1952). The heritability (Broad sense) using the formula of Burton and Devane (1953), genetic advance as per the formula of Johnson et al., (1955) and analysis of co-variance was also analysed as given below.

\section{Test of significance}

If the variance ratio (or) F-calculated value $\left[\mathrm{V}_{\mathrm{t}}\right.$ /EMS] of treatment was greater than the $\mathrm{F}$ table value at $5 \%$ and $1 \%$ level of significance the variance between treatments was considered to be significant. If the F calculated value is less than $F$ tabulated value, the difference between treatments was considered to be non-significant.

\section{Genetic variability}

\section{(i) Mean}

Mean is the average value of the character in a sample, i.e., it is the average of all the observations on a character in sample.

Mean $\bar{X}=\frac{\sum \mathrm{x}}{\mathrm{N}}$ 
Where,

$\Sigma \mathrm{x}=$ Sum of all observations for each character in each replications

$\mathrm{N}=$ Corresponding number of observation

\section{(ii) Range}

It was taken as the difference between the highest and lowest mean value for each character. It is the simple measure of variability and gives an idea of the dispersion or spread of the observations in a sample.

Range $=\mathrm{X}_{\mathrm{n}}-\mathrm{X}_{1}$

Where,

$\mathrm{X}_{\mathrm{n}}=$ Highest mean value of character

$\mathrm{X}_{1}=$ Lowest mean value of character

\section{(iii) Components of variance}

It is defined as the average of the square deviation from the mean or it is the square of the standard deviation. It is an effective measure of variability which permits partitioning of various components.

\section{(a) Genotypic variance}

The genotypic variance ( $\mathrm{VG}$ or $\sigma^{2} \mathrm{~g}$ ) is variance due to the genotype present in the population. This was calculated by the formula suggested by Burton (1952)

$\sigma^{2} \mathrm{~g}=\frac{\mathrm{MS}_{\mathrm{t}}-\text { EMS }}{\text { No. of replication }(\mathrm{r})}$

Where,

$\mathrm{MS}_{\mathrm{t}}=$ Mean sum of squares due to treatment

EMS $=$ Error mean sum of squares

\section{(b) Phenotypic variance}

Phenotypic variance (VP or $\sigma^{2} p$ ) denotes the total variance present in a population for particular character and is calculated by following formula.
Phenotypic variance $\left(\sigma^{2} p\right)=$ Genotypic variance + Error variance

\section{(c) Environmental variance}

The environmental variance (VE or $\sigma^{2} \mathrm{e}$ ) is the variance due to environment deviation.

$\mathrm{VE}=\mathrm{EMS}$

\section{(iv) Standard error of mean (SEM)}

Standard error of mean was calculated by following formula

$\mathrm{SEM}=\sqrt{\frac{2 E M S}{r}}$

\section{(v) Critical differences (CD)}

The critical difference was calculated by following formula

$\mathrm{CD}=\sqrt{\frac{2 E M S}{r}} \times \mathrm{t}$ value

Where,

$\mathrm{t}$ value $=$ table value at error degree of freedom at $5 \%$ level of significance

$\mathrm{r} \quad=\quad$ Number of replication

EMS $=$ Error mean sum of squares

Significant ' $F$ ' value indicates that there is significant difference among the treatments. But to compare any two particular treatments, it is tested against $C D$ value.

\section{(vi) Coefficient of variation $(\mathrm{CV})$}

A measurement of variance which is independent of the unit of measurement is provided by the standard deviation expressed as percentage of mean. This is known as ccoefficient of variation $(\mathrm{CV})$. 
$\mathrm{CV}(\%)=\frac{\text { Standard deviation }}{\text { Mean }} \times 100$

The phenotypic coefficient of variation (PCV), genotypic coefficient of variation (GCV) and environmental coefficient of variation (ECV) were calculated by the formula given by Burton (1952).

\section{(a) Phenotypic coefficient of variation}

$\begin{array}{ll}\mathrm{PCV} \\ (\%)\end{array} \quad=\frac{\begin{array}{l}\text { Phenotypic } \\ \text { deviation }\end{array}}{\text { Grand Mean }} \times$

$$
=\frac{\sqrt{\mathrm{VP}}}{\overline{\mathrm{X}}} \times 100
$$

(b) Genotypic coefficient of variation

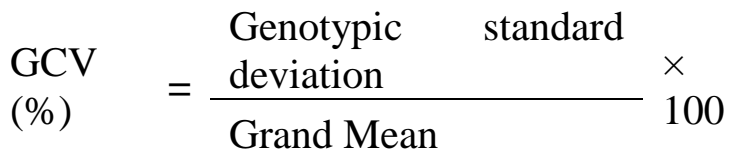

$$
=\frac{\sqrt{\mathrm{VG}}}{\overline{\mathrm{X}}} \times 100
$$

(c) Environmental coefficient of variation

$\begin{aligned} & \text { ECV } \\ & (\%)\end{aligned}=\frac{\begin{array}{l}\text { Error } \\ \text { deviation }\end{array}}{\text { Grand Mean }} \times \frac{\text { standard }}{100}$

$$
=\frac{\sqrt{\mathrm{VE}}}{\overline{\mathrm{X}}} \times 100
$$

\section{Heritability (Broad sense)}

Heritability in broad sense was calculated using the formula suggested by Burton and Devane (1953).

$h^{2}=\frac{V G}{V P} \times 100$

Where,

$\mathrm{h}^{2}=$ Heritability

VG $\left(\sigma^{2} \mathrm{~g}\right)=$ genotypic variance

$\operatorname{VP}\left(\sigma^{2} \mathrm{p}\right)=$ phenotypic variance

Heritability $(\%)=$ Heritability coefficient $\times$ 100

\section{Genetic advance}

Improvement in the mean genotype value of selected plants over the parental population is known as genetic advance. The genetic advance i.e., the expected genetic gain was worked out by using the formula suggested by Johnson et al., (1955).

$$
\begin{aligned}
\text { G.A. }= & \frac{\sigma^{2} g}{\sigma^{2} p} \mathrm{k} \cdot \sigma \mathrm{p} \\
& =\quad \mathrm{h}^{2} \cdot \mathrm{K} \cdot \sigma \mathrm{p}
\end{aligned}
$$

Where,

$\mathrm{h}^{2}=$ Heritability coefficient

$\mathrm{K}=$ Selection differential standard units which is 2.06 for $5 \%$ selection intensity

$\sigma \mathrm{p}=$ Phenotypic standard deviation

G.A. $=$ Genetic advance

\section{Genetic advance as percent of mean (GA \% M)}

It was calculated by the following formula:

Genetic Advance as Percentage of Mean $=\left(\frac{G A}{\bar{X}}\right) \times 100$ 
$\mathrm{GA}=$ Genetic advance

$\overline{\mathrm{X}}=$ Mean of character

Analysis of covariance

Analysis of covariance was worked out for different character combinations. It is helpful in determining the correlation coefficient between different characters. The table for analysis of covariance was formed by arranging the sum of products in the following manners.

\section{Skeleton of Analysis of covariance (ANCOVA)}

\begin{tabular}{|c|c|c|c|c|}
\hline $\begin{array}{l}\text { Source of } \\
\text { variation }\end{array}$ & d.f & S.P. & M.S.P. & $\begin{array}{l}\text { Expected mean sum o } \\
\text { squares }\end{array}$ \\
\hline Replication & $(\mathrm{r}-1)$ & RSP & Cov.r & $\sigma^{2} e(x y)+g \sigma^{2} r(x y)$ \\
\hline Treatment & $(\mathrm{n}-1)$ & $\operatorname{TrSP}$ & Cov.t & $\sigma^{2} e(x y)+r \sigma^{2} g(x y)$ \\
\hline Error & $(\mathrm{r}-1)(\mathrm{n}-1)$ & ErSP & Cov.e & $\sigma^{2} e(x y)$ \\
\hline Total & (nt-1) & TSP & & \\
\hline
\end{tabular}

\section{Covariance}

\section{(a) Genotypic covariance}

Genotypic covariance was calculated by following formula:

Cov.g $=\frac{\text { Cov.t }- \text { Cov.e }}{\text { Number of replication }(r)}$

\section{(b) Phenotypic covariance}

Phenotypic was calculated by following formula:

Cov. $\mathrm{p}=$ Cov $\cdot \mathrm{g}+$ Cov.e

\section{Results and Discussion}

The present investigation entitled "Studies on genetic variability and association among different morpho-physiological traits and their relation with heat tolerance in wheat" was designed to compute the different genetic parameters for eleven traits in fifty genotypes of wheat and results obtained are presented in the following heads.

\section{Analysis of Variance}

The analysis of variance for different characters is presented in Table 1 .

The results showed highly significant difference for the most of the characters under study among fifty genotypes. This suggested that there is an inherent genetic difference among the genotypes.

Variability, heritability and genetic advance

The per se performance (mean) of genotypes for all the quantitative traits have been presented in Table 2. The estimates of range, mean, phenotypic coefficient of variation (PCV), genotypic coefficient of variation (GCV), heritability (broad sense) and genetic advance are presented in Table 3 .

Considerable range of variation was observed for all the quantitative traits under study indicating enough scope for bringing about improvement in desirable direction. 


\section{Variance (Phenotypic and Genotypic)}

Estimates of phenotypic $\left(\left(\sigma^{2} p\right)\right.$ variance was obtained for different traits. Estimates of phenotypic variance $\left(\sigma^{2} p\right)$ were higher than genotypic variance $\left(\sigma^{2} \mathrm{~g}\right)$. A wide range of $\left(\sigma^{2} p\right)$ was observed for days to heading, chlorophyll contents, days to anthesis, plant height, spike length, spikelets per spike, grain weight and plot yield while moderate range of variance showed by the traits like days to maturity and canopy temperature depression at different phenological stages.

\section{Coefficient of variation}

Data presented in Table 3 indicated considerable variation for all traits under study with a wide range of phenotypic as well as genotypic coefficient of variation. In general, as could normally be expected, the values of phenotypic variance were higher than those of genotypic variance for all the traits. The relative magnitudes of the phenotypic as well as genotypic variances between the traits were compared based on the phenotypic and genotypic coefficient of variation.

The result of phenotypic coefficient of variation revealed that 1000 grain weight exhibited the highest phenotypic coefficient of variation (12.51) followed by grains per spike (11.89), spikelet's per spike (9.01), spike length (8.92) and yield per plot(7.83). Also chlorophyll content and CTD at different stages showed wide phenotypic coefficient of variation while, the remaining characters showed moderate to low phenotypic coefficient of variation.

Genotypic coefficient of variation was also high for 1000 grain weight (11.55) followed by grains per spike (10.58), spike length (8.24), spikelet per spike (7.41) and yield per plot (6.79). Also chlorophyll content and CTD at different stages showed wide genotypic coefficient of variation. And remaining characters showed moderate to low genotypic coefficient of variation.

In general, the values of genotypic coefficient of variation (GCV) were lower than their respective phenotypic coefficient of variation (PCV). The difference between the values of PCV and GCV was very small for almost all the traits indicating less influence of environment in expression of these traits.

\section{Heritability and genetic advance}

The estimates of heritability (broad sense) and genetic advance expressed as percent of mean have been presented in Table 3 .

The heritability ranged from 68 percent to 93 percent. High heritability estimate was exhibited by days to heading (93), days to anthesis (93), 1000 grain weight (85), plant height (85), spike length (85), and yield per plot (75). The remaining traits showed moderate levels of heritability.

The plant estimate of genetic advance as percent of mean was the highest for yield per 1000 grain weight (28.06) followed by grains per spike (24.86), spike length (20.11), spikelet's per spike (16.10), yield per plot (15.57) and the remaining traits showed narrow genetic advance. Also, estimate of genetic advance for chlorophyll content and CTD at different stages showed high to moderate percentage values.

Yield is a complex character which is controlled by association of various characters. Thus, information on association of yield attributes and their direct and indirect effects on grain yield are of paramount significance. Generally yield is polygenic in nature and has low heritability and thus, direct selection for increased yield is not sufficiently effective. Grafius (1959) introduced a 
geometrical concept for components of yield and suggested that it would be easier to increase total yield by selecting for yield components which are more simply inherited than yield per se.

Therefore, the present investigation was planned to get the precise information regarding various genetic parameters discussed under the following heads:

Variability

Heritability and genetic advance

Correlation

The analysis of variance showed highly significant variation for most of the characters indicating thereby presence of considerable genotypic differences among the germplasm of wheat undertaken in the present investigation.

\section{Genetic variability}

The development of an effective plant breeding programme is dependent upon the existence of genetic variability. The efficiency of selection largely depends upon the magnitude of genetic variability present in the plant population. Thus, the traits which showed wide range of variation like days to heading, days to anthesis, plant height, yield per plot, grains per spike and 1000 seed weight have maximum scope of selection.

An insight into the extent of genotypic and phenotypic variances existing in the germplasm would be of immense value. The characters like plant height, grains per spike, 1000 grain weight and plot yield exhibited higher values of phenotypic variance while other traits also showed similar trend. This suggested that there is a good scope of selection for these factors. This can be supported by the findings of Singh et al., (2001), Cheema et al., (2006).
The variance measures the variation within a particular trait, but it does not provide a real measure for comparison of variances between different traits. The term coefficient of variation truly provides a relative measure of variance among the different traits. Many early workers including Pawar et al., (1988), Hanchinal and Maled (1995), Sharma et al., (1998) and Kamboj et al., (2000) reported high variability for different traits in wheat.

The phenotypic coefficient of variation was higher than their respective genotypic coefficient of variation for all the traits under study which is in accordance with the studies of Dixit (1990), Singh et al., (2001), Sharma and Garg (2002). The plant height, spikelets per spike, grains per spike, 1000 grain weight and yield per plot showed maximum phenotypic coefficient of variation. This variation was minimum for days to maturity, as reported by Sander et al., (2002). Thus, the characters showing maximum phenotypic coefficient of variation would be considered while making selection in spite of influence of environment to a certain extent. The results of high phenotypic coefficient of variation for plant height, grains per spike and 1000 grain weight were in accordance with studies of Bergale et al., (2001), Mohammad et al., (2001), Fida et al., (2003), Bhoite et al., (2008). High for yield per plot was reported by Sharma et al., (1998).

As far as genotypic coefficient of variation is concerned, three characters, viz. grains per spike, 1000 grain weight and spike length showed maximum variation. These results showed conformity with the findings of Panwar and Singh (2000), Bergale et al., (2001). The minimum value of genotypic coefficient of variation was observed for days to maturity. This was in Singh et al., (1996). Thus, the traits with high GCV are to be considered during selection. 
Table.1 Analysis of variance (ANOVA) for all the characters under study in fifty lines of wheat

\begin{tabular}{|c|c|c|c|c|c|c|c|c|c|c|}
\hline \multicolumn{11}{|c|}{ Mean Sum of Square (MSS) } \\
\hline Source & $\begin{array}{c}\text { Degree } \\
\text { of } \\
\text { freedom }\end{array}$ & $\begin{array}{l}\text { Days to } \\
\text { heading }\end{array}$ & $\begin{array}{l}\text { Days to } \\
\text { anthesis }\end{array}$ & $\begin{array}{c}\text { Plant } \\
\text { height } \\
(\mathrm{cm})\end{array}$ & $\begin{array}{c}\text { Spike } \\
\text { length } \\
(\mathrm{cm})\end{array}$ & $\begin{array}{c}\text { Spikelet's } \\
\text { per spike } \\
\text { (No.) }\end{array}$ & $\begin{array}{l}\text { Days to } \\
\text { maturity }\end{array}$ & $\begin{array}{c}\text { Grains } \\
\text { per spike }\end{array}$ & $\begin{array}{c}1000 \\
\text { grain } \\
\text { weight } \\
(\mathrm{g})\end{array}$ & $\begin{array}{c}\text { Yield } \\
\text { per plot } \\
\text { (g) }\end{array}$ \\
\hline Replication & 2 & 0.54 & 1.52 & 0.49 & 0.42 & 2.93 & 0.02 & 0.051 & 11.91 & 1446 \\
\hline Treatment & 49 & $19.42^{* *}$ & $19.34^{* *}$ & $58.38^{* *}$ & $1.79^{* *}$ & $5.19^{* *}$ & $5.27 * *$ & $77.74 * *$ & $63.98^{* *}$ & $6761^{* *}$ \\
\hline Error & 98 & 0.47 & 0.48 & 3.30 & 0.10 & 0.71 & 0.80 & 6.27 & 3.63 & 664 \\
\hline
\end{tabular}

Analysis of variance (ANOVA) for all the characters under study in fifty lines of wheat

\begin{tabular}{|l|c|c|c|c|c|c|c|c|c|}
\hline \multicolumn{7}{|c|}{ Mean Sum of Square (MSS) } \\
\hline Source & $\begin{array}{c}\text { Degree of } \\
\text { freedom }\end{array}$ & $\begin{array}{c}\text { Chlorophyll } \\
\text { content 1 }\end{array}$ & $\begin{array}{c}\text { Chlorophyll } \\
\text { content 2 }\end{array}$ & CTD 1 & CTD 2 & CTD 3 & CTD 4 & CTD 5 & CTD 6 \\
\hline Replication & 2 & 1.01 & 0.18 & 1.64 & 0.11 & 0.38 & 0.05 & 0.007 & $\mathbf{0 . 5 2}$ \\
\hline Treatment & $49^{* *}$ & $10.93^{* *}$ & $16.58^{* *}$ & $1.64^{*}$ & $1.82^{* *}$ & $3.64^{* *}$ & $3.71^{* *}$ & $1.87^{* *}$ & $\mathbf{1 . 5 9}^{*}$ \\
\hline Error & $\mathbf{9 8}$ & $\mathbf{1 . 4 3}$ & $\mathbf{2 . 5 5}$ & $\mathbf{0 . 1 3}$ & $\mathbf{0 . 1 5}$ & $\mathbf{0 . 1 4}$ & $\mathbf{0 . 1 1}$ & $\mathbf{0 . 1 3}$ & $\mathbf{0 . 3 2}$ \\
\hline
\end{tabular}

*Significant at $\mathrm{P} \leq 0.05$ level of significance

$* *$ Significant at $\mathrm{P} \leq 0.01$ level of significance 
Table.2 Mean performance of the 50 genotypes of wheat for all traits under study

\begin{tabular}{|c|c|c|c|c|c|c|c|c|c|}
\hline $\begin{array}{c}\text { Character/ } \\
\text { genotype Sl. } \\
\text { No. }\end{array}$ & $\begin{array}{l}\text { Days to } \\
\text { heading }\end{array}$ & $\begin{array}{l}\text { Days to } \\
\text { anthesis }\end{array}$ & $\begin{array}{l}\text { Plant } \\
\text { height } \\
(\mathrm{cm})\end{array}$ & $\begin{array}{l}\text { Spike } \\
\text { length } \\
(\mathrm{cm})\end{array}$ & $\begin{array}{c}\text { Spikelet per } \\
\text { spike } \\
\text { (number) }\end{array}$ & $\begin{array}{l}\text { Days to } \\
\text { maturity }\end{array}$ & $\begin{array}{l}\text { Grains per } \\
\text { spike }\end{array}$ & $\begin{array}{l}1000 \text { grain } \\
\text { weight } \\
(\mathrm{g})\end{array}$ & $\begin{array}{l}\text { Yield per } \\
\text { plot } \\
\text { (kg.) }\end{array}$ \\
\hline 1. & 70.33 & 3.67 & 98.44 & 9.17 & 16.00 & 112.33 & 51.00 & 37.74 & 2.09 \\
\hline 3. & 80.33 & 83.67 & 84.89 & 8.14 & 16.17 & 115.00 & 45.50 & 32.66 & 1.78 \\
\hline 4. & 81.33 & 84.33 & 97.22 & 8.87 & 16.00 & 114.67 & 44.00 & 47.33 & 2.35 \\
\hline 7. & 80.67 & 3.67 & 96.33 & .32 & 14.83 & 113.00 & 47.17 & 39.32 & 2.17 \\
\hline 8. & 82.33 & 85.33 & 7.78 & 9.50 & 15.33 & 113.33 & 40.67 & 40.94 & 2.08 \\
\hline 9. & 82.67 & 86.33 & 99.00 & 9.25 & 15.50 & 114.00 & 45.83 & 43.15 & 2.03 \\
\hline 10. & 83.00 & 86.33 & 98.89 & 8.91 & 15.00 & 114.33 & 47.33 & 43.35 & 2.25 \\
\hline 11. & 84.67 & 88.67 & 71.22 & 9.68 & 15.33 & 115.33 & 45.67 & 45.70 & 2.33 \\
\hline 15. & 82.67 & 85.33 & 98.44 & 9.44 & 18.00 & 115.33 & 43.83 & 37.72 & 2.12 \\
\hline 16. & 83.67 & 86.00 & 100.33 & 8.40 & 16.83 & 115.67 & 42.67 & 42.12 & 2.08 \\
\hline 17. & 82.67 & 85.67 & 98.22 & 8.83 & 13.33 & 115.33 & 32.83 & 47.77 & 2.17 \\
\hline 18. & 83.33 & 86.33 & 100.44 & 9.49 & 13.50 & 117.00 & 40.83 & 40.00 & 1.97 \\
\hline 19. & 81.67 & 84.67 & 91.67 & 9.01 & 18.00 & 115.00 & 50.17 & 42.42 & 2.21 \\
\hline 20. & 76.67 & 80.33 & 91.00 & 7.19 & 17.17 & 113.33 & 42.00 & 49.07 & 1.92 \\
\hline 21. & 82.67 & 86.33 & 96.22 & 8.87 & 15.83 & 115.67 & 42.67 & 31.21 & 1.70 \\
\hline 22. & 77.00 & 79.67 & 102.33 & 8.93 & 16.00 & 113.00 & 44.83 & 37.09 & 2.16 \\
\hline 23. & 84.33 & 87.67 & 99.89 & 8.19 & 15.17 & 116.33 & 43.33 & 39.44 & 2.07 \\
\hline 24. & 78.67 & 82.67 & 100.22 & 7.83 & 17.33 & 113.00 & 49.17 & 38.39 & 2.05 \\
\hline
\end{tabular}


Table 2 Contd...

\begin{tabular}{|c|c|c|c|c|c|c|c|c|c|}
\hline & & & & & & & \\
\hline 26. & 81.00 & 84.33 & 101.33 & 8.11 & 16.67 & 112.67 & 48.83 & 34.98 & 2.26 \\
\hline 27. & 80.33 & 84.00 & 103.89 & 9.13 & 17.17 & 111.00 & 49.83 & 31.93 & 2.21 \\
\hline 28. & 84.00 & 87.00 & 92.22 & 8.08 & 17.50 & 115.00 & 51.83 & 29.72 & 1.85 \\
\hline 29. & 81.00 & 85.00 & 94.22 & 8.90 & 15.33 & 114.00 & 41.67 & 38.09 & 1.96 \\
\hline 30. & 80.33 & 84.00 & 97.78 & 8.79 & 14.33 & 112.33 & 44.83 & 41.30 & 2.12 \\
\hline 31. & 81.00 & 84.67 & 96.55 & 9.12 & 16.50 & 113.00 & 38.67 & 40.67 & 2.23 \\
\hline 32. & 81.33 & 84.33 & 98.89 & 10.22 & 16.17 & 113.33 & 42.17 & 34.30 & 2.11 \\
\hline 33. & 78.00 & 81.00 & 93.44 & 9.12 & 16.17 & 114.00 & 48.50 & 36.35 & 2.06 \\
\hline 34. & 82.33 & 85.67 & 101.22 & 9.08 & 15.67 & 114.33 & 44.50 & 42.88 & 1.99 \\
\hline 35. & 82.00 & 86.00 & 101.67 & 8.25 & 16.67 & 113.33 & 50.00 & 36.77 & 2.21 \\
\hline 36. & 82.67 & 86.33 & 103.00 & 8.84 & 16.83 & 114.67 & 47.67 & 44.47 & 2.19 \\
\hline 37. & 82.67 & 86.33 & 97.67 & 9.06 & 17.00 & 113.00 & 46.00 & 41.67 & 2.19 \\
\hline 38. & 83.33 & 86.33 & 101.67 & 9.90 & 16.50 & 114.67 & 50.83 & 35.58 & 2.06 \\
\hline 39. & 82.00 & 84.67 & 102.33 & 9.09 & 16.17 & 113.00 & 50.17 & 32.85 & 2.01 \\
\hline 40. & 78.67 & 82.33 & 96.00 & 8.32 & 14.33 & 112.67 & 41.17 & 41.99 & 2.31 \\
\hline 41. & 80.00 & 83.33 & 96.11 & 10.12 & 19.17 & 114.00 & 57.17 & 32.97 & 2.45 \\
\hline 42. & 80.67 & 84.00 & 98.22 & 7.84 & 14.17 & 112.33 & 41.17 & 44.33 & 2.15 \\
\hline 43. & 81.67 & 84.67 & 99.89 & 9.29 & 17.00 & 114.67 & 49.17 & 31.22 & 2.11 \\
\hline 44. & 82.67 & 86.33 & 103.00 & 9.57 & 18.83 & 115.00 & 58.17 & 36.85 & 2.20 \\
\hline 45. & 83.33 & 87.00 & 109.22 & 11.30 & 18.00 & 114.67 & 51.67 & 37.41 & 1.95 \\
\hline 46. & 81.33 & 85.00 & 93.89 & 8.47 & 15.00 & 113.00 & 38.33 & 38.16 & 2.12 \\
\hline 47. & 82.00 & 85.33 & 97.22 & 9.34 & 17.67 & 111.67 & 53.50 & 42.42 & 2.07 \\
\hline 48. & 81.33 & 85.00 & 95.33 & 8.63 & 16.17 & 113.33 & 40.67 & 33.42 & 2.13 \\
\hline 49. & 81.67 & 85.00 & 96.00 & 9.10 & 16.33 & 112.67 & 43.00 & 41.21 & 2.07 \\
\hline 50. & 82.00 & 85.33 & 93.22 & 8.42 & 15.33 & 114.00 & 50.00 & 37.31 & 2.09 \\
\hline Total mean & 81.32 & 84.68 & 97.75 & 9.06 & 16.28 & 114.06 & 46.13 & 38.85 & 2.10 \\
\hline
\end{tabular}


Table.3 Mean performance of the 50 genotypes of wheat for all traits under study

\begin{tabular}{|c|c|c|c|c|c|c|c|c|}
\hline $\begin{array}{c}\text { Character/ } \\
\text { genotype Sl. No }\end{array}$ & Chlorophyll content 1 & Chlorophyll content 2 & CTD 1 & CTD 2 & CTD 3 & CTD 4 & CTD 5 & CTD 6 \\
\hline 1. & 46.70 & 46.70 & 5.50 & 5.90 & 5.07 & 6.37 & 4.90 & $(1.05)$ \\
\hline 2. & 40.53 & 39.30 & 6.50 & 5.80 & 3.83 & 6.00 & 4.27 & $(0.50)$ \\
\hline 3. & 47.29 & 44.13 & 6.17 & 5.03 & 3.83 & 6.03 & 4.73 & $(0.75)$ \\
\hline 4. & 48.00 & 44.20 & 6.43 & 5.03 & 5.07 & 6.07 & 5.83 & $(0.60)$ \\
\hline 5. & 47.13 & 46.20 & 6.00 & 5.80 & 4.40 & 5.70 & 5.00 & 0.15 \\
\hline 6. & 45.36 & 46.97 & 5.83 & 5.57 & 4.80 & 5.97 & 4.83 & $(0.85)$ \\
\hline 7. & 46.93 & 43.97 & 6.47 & 6.80 & 4.70 & 6.47 & 6.33 & 0.20 \\
\hline 8. & 44.33 & 42.97 & 6.30 & 5.80 & 5.00 & 6.80 & 6.47 & 0.30 \\
\hline 9. & 43.02 & 38.43 & 6.40 & 5.97 & 5.30 & 6.53 & 5.47 & 0.65 \\
\hline 10. & 44.41 & 43.93 & 6.10 & 6.50 & 4.57 & 6.37 & 6.17 & $(0.80)$ \\
\hline 11. & 44.11 & 41.07 & 6.37 & 4.83 & 4.87 & 6.67 & 6.97 & 0.75 \\
\hline 12. & 43.02 & 39.07 & 5.50 & 4.50 & 4.23 & 6.80 & 5.73 & 0.40 \\
\hline 13. & 44.11 & 46.17 & 6.30 & 5.03 & 4.30 & 7.03 & 5.00 & $(0.15)$ \\
\hline 14. & 46.92 & 46.03 & 6.13 & 5.70 & 4.07 & 5.93 & 5.90 & 0.45 \\
\hline 15. & 46.20 & 41.53 & 6.70 & 5.17 & 4.47 & 6.27 & 6.20 & 0.65 \\
\hline 16. & 43.94 & 42.83 & 5.80 & 6.27 & 4.37 & 6.33 & 6.13 & 0.45 \\
\hline 17. & 46.38 & 43.10 & 6.10 & 4.83 & 3.97 & 7.13 & 6.00 & 1.15 \\
\hline 18. & 46.09 & 43.83 & 6.27 & 6.00 & 4.00 & 5.67 & 6.37 & 1.20 \\
\hline 19. & 42.50 & 42.47 & 5.97 & 5.70 & 4.40 & 5.93 & 6.33 & 0.55 \\
\hline 20. & 47.41 & 43.97 & 6.30 & 5.60 & 3.27 & 6.57 & 5.60 & 0.85 \\
\hline 21. & 43.86 & 43.30 & 4.07 & 6.17 & 4.10 & 6.87 & 5.57 & 0.25 \\
\hline 22. & 45.93 & 40.93 & 6.63 & 6.13 & 4.03 & 6.60 & 4.80 & $(0.35)$ \\
\hline 23. & 48.79 & 47.37 & 6.37 & 5.67 & 3.93 & 6.00 & 5.00 & 1.55 \\
\hline 24. & 47.30 & 46.40 & 5.87 & 5.67 & 5.00 & 6.97 & 4.60 & 0.05 \\
\hline 25. & 47.24 & 43.30 & 6.17 & 4.70 & 4.50 & 6.93 & 4.83 & 1.55 \\
\hline
\end{tabular}


Table Contd....

\begin{tabular}{|c|c|c|c|c|c|c|c|c|}
\hline 26. & 45.91 & 45.10 & 6.07 & 5.23 & 5.17 & 6.67 & 5.83 & (0.15 \\
\hline 27. & 46.78 & 43.10 & 5.63 & 6.27 & 4.40 & 6.83 & 4.23 & $(0.60$ \\
\hline 28. & 43.06 & 43.00 & 5.60 & 4.50 & 4.50 & 6.73 & 4.60 & (0.10 \\
\hline 29. & 40.82 & 38.70 & 6.17 & 5.87 & 4.63 & 6.00 & 5.03 & 0.20 \\
\hline 30. & 44.94 & 45.63 & 6.50 & 5.73 & 3.80 & 6.30 & 5.30 & 0.20 \\
\hline 31. & 42.11 & 43.73 & 7.00 & 5.57 & 3.67 & 7.47 & 5.03 & (0.15 \\
\hline 32. & 42.81 & 43.27 & 6.63 & 4.53 & 4.83 & 7.60 & 6.00 & (0.10 \\
\hline 33. & 44.27 & 42.83 & 6.00 & 4.37 & 4.93 & 6.37 & 4.63 & 0.95 \\
\hline 34. & 44.97 & 43.13 & 6.93 & 6.10 & 4.03 & 6.83 & 5.47 & 1.15 \\
\hline 35. & 44.40 & 42.77 & 6.77 & 5.97 & 4.03 & 7.07 & 6.00 & 1.80 \\
\hline 36. & 43.93 & 41.30 & 7.00 & 5.13 & 4.53 & 7.30 & 6.27 & 2.00 \\
\hline 37. & 44.37 & 40.43 & 6.70 & 5.20 & 4.20 & 7.40 & 5.60 & 1.60 \\
\hline 38. & 44.96 & 44.10 & 7.03 & 6.37 & 3.83 & 6.83 & 5.50 & 1.40 \\
\hline 39. & 45.17 & 45.03 & 6.93 & 6.37 & 4.23 & 7.37 & 5.57 & 1.45 \\
\hline 40. & 47.57 & 47.37 & 6.53 & 6.10 & 5.27 & 7.00 & 5.67 & 0.40 \\
\hline 41. & 44.12 & 41.60 & 6.53 & 6.03 & 3.97 & 6.93 & 6.23 & 0.95 \\
\hline 42. & 44.02 & 42.67 & 6.37 & 6.10 & 3.90 & 7.20 & 5.00 & 1.30 \\
\hline 43. & 44.46 & 43.50 & 6.10 & 5.87 & 4.03 & 7.00 & 5.83 & 1.50 \\
\hline 44. & 45.49 & 45.77 & 6.60 & 6.27 & 4.37 & 7.27 & 5.97 & 1.20 \\
\hline 45. & 44.86 & 41.20 & 6.77 & 6.90 & 4.33 & 6.70 & 6.03 & 1.65 \\
\hline 46. & 48.36 & 48.20 & 6.43 & 6.30 & 3.93 & 7.03 & 5.93 & 1.40 \\
\hline 47. & 48.36 & 46.20 & 6.43 & 5.40 & 4.30 & 6.93 & 5.80 & 1.65 \\
\hline 48. & 46.02 & 44.43 & 6.17 & 5.97 & 4.37 & 6.83 & 5.80 & 1.15 \\
\hline 49. & 46.69 & 47.10 & 6.27 & 5.80 & 4.03 & 7.00 & 5.53 & 0.90 \\
\hline 50. & 46.21 & 44.43 & 6.40 & 6.20 & 4.20 & 7.07 & 6.03 & 1.10 \\
\hline mean & 45.24 & 43.66 & 6.28 & 5.69 & 4.35 & 6.67 & 5.56 & 0.58 \\
\hline
\end{tabular}

Values in the bracket indicates the negative readings. 
Table.4 Range, Mean, SEm ( \pm ), Phenotypic and genotypic variance, PCV, GCV, heritability, genetic advance as percentage of mean for all characters under study in wheat

\begin{tabular}{|c|c|c|c|c|c|c|c|c|c|c|}
\hline \multicolumn{11}{|c|}{ Mean Sum of Square (MSS) } \\
\hline \multicolumn{2}{|c|}{ Characters } & $\begin{array}{l}\text { Days to } \\
\text { heading }\end{array}$ & $\begin{array}{l}\text { Days to } \\
\text { anthesis }\end{array}$ & $\begin{array}{l}\text { Plant } \\
\text { height } \\
\text { (cm) }\end{array}$ & $\begin{array}{c}\text { Spike } \\
\text { length } \\
(\mathrm{cm})\end{array}$ & $\begin{array}{l}\text { Spikelet's } \\
\text { per spike } \\
\text { (no.) }\end{array}$ & $\begin{array}{l}\text { Days to } \\
\text { maturity }\end{array}$ & $\begin{array}{c}\text { Grains } \\
\text { per } \\
\text { spike }\end{array}$ & $\begin{array}{l}1000 \text { grain } \\
\text { weight } \\
\text { (g) }\end{array}$ & $\begin{array}{c}\text { Yield per } \\
\text { plot } \\
(\mathrm{g})\end{array}$ \\
\hline \multirow[t]{2}{*}{ Range } & minimum & 70.33 & 73.67 & 84.89 & 7.19 & 13.33 & 111.00 & 32.83 & 29.72 & $1,700.00$ \\
\hline & maximum & 84.66 & 88.67 & 111.00 & 11.30 & 19.33 & 117.00 & 58.17 & 49.07 & 2446.67 \\
\hline \multicolumn{2}{|c|}{ Grand mean } & 81.32 & 84.68 & 98.35 & 9.12 & 16.47 & 114.06 & 46.13 & 38.85 & 2098.27 \\
\hline \multicolumn{2}{|c|}{$\operatorname{SEm}( \pm)$} & 0.3938 & 0.4025 & 1.0491 & 0.1794 & 0.4873 & 0.5149 & 1.4456 & 1.0993 & 47.0514 \\
\hline \multicolumn{2}{|c|}{ Phenotypic variance } & 6.79 & 6.77 & 21.66 & 0.66 & 2.20 & 2.29 & 30.10 & 23.75 & 26966.10 \\
\hline \multicolumn{2}{|c|}{ Genotypic variance } & 6.32 & 6.29 & 18.36 & 0.57 & 1.49 & 1.49 & 23.83 & 20.12 & 20324.60 \\
\hline \multicolumn{2}{|c|}{ PCV (percent) } & 3.20 & 3.07 & 4.73 & 8.92 & 9.01 & 1.33 & 11.89 & 12.54 & 7.83 \\
\hline \multicolumn{2}{|c|}{ GCV (percent) } & 3.09 & 2.96 & 4.36 & 8.24 & 7.41 & 1.07 & 10.58 & 11.55 & 6.79 \\
\hline \multicolumn{2}{|c|}{ Heritability(percent) } & 0.93 & 0.93 & 0.85 & 0.85 & 0.68 & 0.65 & 0.79 & 0.85 & 0.75 \\
\hline \multicolumn{2}{|c|}{$\begin{array}{l}\text { Genetic advance as } \\
\text { percent of mean }\end{array}$} & 6.15 & 5.88 & 8.26 & 15.69 & 12.57 & 1.78 & 19.40 & 21.89 & 12.15 \\
\hline
\end{tabular}




\begin{tabular}{|l|c|c|c|c|c|c|c|c|}
\hline \multicolumn{7}{|c|}{ Mean Sum of Square (MSS) } \\
\hline Characters & $\begin{array}{l}\text { Chlorophyl } \\
\text { l content 1 }\end{array}$ & $\begin{array}{l}\text { Chlorophyl } \\
\text { l content 2 }\end{array}$ & CTD 1 & CTD 2 & CTD 3 & CTD 4 & CTD 5 & CTD 6 \\
\hline & & & & & & \\
\hline
\end{tabular}




\section{Heritability and genetic advance}

The GCV provides a measure for comparison of variability and sometime gives some indication regarding validity of traits for selection. However, it does not provide clear picture of the extent of genetic gain to be expected from selection of phenotypic traits, unless heritable fraction of variation (heritability) is known (Burton, 1952). The effectiveness of selection for a trait depends on the expression of phenotypic differences among the genotypes in a population, a concept referred to as heritability. The heritability of a character has major impact on the method chosen for population improvement (Table 4).

In the present experiment all the traits exhibited high heritability. Similar results were published by Dwivedi et al., (2003) and Zecevic (2010). Days to heading and days to anthesis showed the highest heritability followed by plant height, spike length and 1000 grain weight. The lowest heritability was exhibited by days to maturity. Since high heritability indicates the least influence of the environment, one should emphasize the attention on characters having high heritability.

High heritability estimates accompanied by large genetic advance would be desirable for exploitation of variability in desirable direction. The breeder should be cautious in making selection based on heritability as it includes both additive and non-additive gene action. High genetic advance as percent of mean indicates predominance of additive effects leading to further improvement of their performance. Thus, heritability values coupled with genetic advance would be more reliable and useful in formulating selection procedure.

In the present set of materials, high heritability coupled with high genetic advance as percent of mean was recorded for 1000 grain weight, yield per plot, spike length and filled grains per spike indicating effectiveness of selection for the improvement of these traits. These results showed similarity with the findings of Masood et al., (1986), Deswal et al., (1996), Panwar and Singh (2000), Cheema et al., (2006) and Bhoite et al., (2008). Also CTD and chlorophyll content at different stages exhibited high heritability coupled with moderate to high genetic advance indicating their effectiveness for selection of genotypes tolerant to high temperature. Similar observations were reported by Reynolds et al., (1994). Spikelet per spike exhibited moderate heritability coupled with high genetic advance indicating that selection will be effective. Days to heading and days to anthesis showed high heritability coupled with low genetic advance indicating that low heritability is due environmental effects and thus, selection will be ineffective.

From the above discussion it can be concluded that the analysis of variance showed the highly significant differences among the genotypes for all the characters studied. Considerable range of variations were observed for all the traits studied indicating that there ample scope for selection of promising genotypes from the present set of genotypes for yield improvement in wheat.

From the genetic variability studies indicated that high estimates of GCV and PCV were observed for traits like 1000 grain weight, grains per spike, spikelet's per spike, spike length and yield per plot indicating their importance in selection for improving the wheat yield. Further, high heritability coupled with high expected genetic advance as percent of mean was also observed for the above mentioned traits indicating the less influence of environmental variance in the inheritance of these traits, which can be further improved by means of simple selection. The correlation 
study revealed that plot yield had strong positive association with 1000 grain weight, spike length and spikelet's per spike. The association studied, indicated that grain yield of wheat can be improved by selecting the genotypes having higher performances for the above characters. Also the results exhibited positive and significant correlation for grain yield and other traits with chlorophyll content and CTD indicating that importance of these characters while breeding for heat tolerance. Days to maturity showed negative significant association with plot yield. This indicates that the selection for early maturity would ultimately be helpful for improving the grain yield.

\section{References}

Allard, R.W., 1960. Principles of plant Breeding. John Willey and Sons. Inc., USA.

Bergale, S., Billore, Mridulla, Halkar, A. S., Ruwali, K. N., Prasad, S. V. S. and Mridulla, B., 2001. Genetic variability, diversity and association of quantitative traits with grain yield in bread wheat. Madras Agri. J. 88 (7-9): 457-461.

Bhoite, K. D., Rasal, R. N. and Gadekar, D. A., 2008. Genetic variability, heritability and genetic advance in durum wheat (Triticum durum L.). J. Maharashtra Agril. Univ. 33 (1): 102103.

Burton, G.W. and Devane., 1953. Estimating heritability in tall fescus from replicated clonal material. J. Agronomy. 45 (3): 473-481.

Burton, G.W., 1952. Quantitative inheritance in grasses. Proceedings of $6^{\text {th }}$ International Grassland Congress. $1: 227-283$

Cheema, N. M., Mian, M. A., and Muhammad, I. G. R. A. M., 2006. Studies on variability and some genetic parameters in spring wheat. Pakistan J.
Agril. Sci. 43 (1/2): 32-35.

Deswal, R. K., Grakh, S. S. and Berwal, K. K., 1996. Genetic variability and characters association between grain yield and its components in wheat. Annals of Biology (Ludhiana). 12 (2): 221-224.

Dixit, S. K., 1990, Variability pattern in durum wheat under different sowing path analysis inland races of bread wheat from South Western Iran. Euphytica. 41: 183-190.

Dwivedi, V. K. and Tyagi, N. K., 2003. Genetic variability in some metric traits and its contribution to yield in wheat (Triticum aestivum L.). Progressive Agri. 3 (1/2): 152-153.

FAO,, 2003. Statistical Year book 2003, Statistical Division, Food and Agricultural Organization, Rome.

FAO., 2008. Statistical Yearbook 2008, Statistical Division, Food and Agricultural Organization, Rome.

Grafius, J. E., 1959. Heterosis in barley. Agron. J., 51: 551-554.

Hanchinal, R. R. and Maled, B. G., 1995. Conservation of summer wheat (Triticum dicoccum) germplasm and their improvement for sustainable production. Proceedings of the National Seminar on Conservation of National Resources for Sustainable Production (November 16-17, 1995).

Johnson, H. W., Robinson, H. F. and Comstock., 1955. Genotypic and phenotypic correlations in soybeans and their implication in selection. Agron. J. 47:477-483.

Kamboj, M. C., Naveen, C., Subhandra, Yadav, R. K. and Chaundra, N., 2000. Genetic analysis of yield and its components in bread wheat (Triticum aestivum L.). Atlas of Agri-BioResearch. 5(1): 41-43.

Masood, M. S., Mujahid and Hashmi, N. I., 1986. Variability studies in wheat under 
rainfed conditions. Pakistan J. Agri. Res. 23: 244-247.

Mohammad, F., Daniel, H., Shahzad, K. and Khan, H., 2001. Heritability estimates for yield and its components in wheat. Sarhad J. Agri. 17(2): 227-234.

Munawar, A. F., Mohammad, K. M., Abdul, A. S. I., 2003. Genetic variability and traits correlation in wheat. Sarhad $J$. Agri. 19 (3): 347-351.

Panse, V. G. and Sukhatme, P. G., 1967. Statistical methods for agricultural workers $2^{\text {nd }} E d n$. Pp. 381, ICAR, New Delhi.

Pawar, S. D., Thete, R. Y. AND Dumbre, A. D., 1988. Estimates of genetic variability parameters in $\mathrm{F}_{2}$ population of wheat. J. Maharashtra Agril. Univ. 13: 210-211.

Reynolds, M. P. and Borlaug, N. E., 2006. Applying innovations and new technologies for international collaborative wheat improvement. $J$. Agril. Sci. 144:99-110.

Reynolds, M. P. Balota, M. Delgado, M. I. B. Amani, I. Fischer, R. A., 1994. Physiological and morphological traits associated with spring wheat yield under hot, irrigated conditions.
Australian J. Plant Physiology. 21 (6): 717-730.

Sander, K., Dwivedi, V. K. and Tyagi, N. K., 2002. Genetic variability in some metric traits and its contribution to yield in wheat (Triticum aestivum L.). Progressive Agriculture. 3 (1/2): 152153.

Sharma, A. K. and Garg, D. K., 2002. Genetic variability in wheat (Triticum aestivum) crosses under different environments. Annals Agri. Res. 23 (3): 497-499.

Sharma, S. P. and Krishnawat, B. R. S., 1998. Genetic variability in wheat under irrigated and moisture stress conditions. Crop Research (Hisar). 16 (3): 314317.

Singh, S. P., Jha, P. B. and Singh, D. N., 2001. Genetic variability for polygenic traits in late sown wheat genotypes. Annals of Agril. Res. 22 (1): 34-36.

Wright, S., 1921. Correlation and Causation. J. Agric. Res. 20:557-558.

Zecevic, V., Boskovic, J., Dimitrijevic, M. and Petrovic, S., 2010. Genetic and phenotypic variability of yield components in wheat (Triticum aestivum L.). Bulgarian J. Agril. Sci. 16 (4): 422-428.

\section{How to cite this article:}

Nishant Bankapur, J.S. Hilli, Ram Dhari and Arun, B. 2018. Studies on Genetic Variability, Heritability, Genetic Advances and Association of Morpho- Physiological Traits and their Relation with Heat Tolerance in Wheat. Int.J.Curr.Microbiol.App.Sci. 7(12): 2725-2742. doi: https://doi.org/10.20546/ijcmas.2018.712.310 